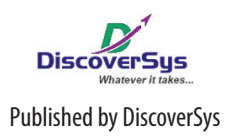

Published by DiscoverSy

\section{Prevalence and determinants of pentavalent booster immunization in children aged three to five years in Denpasar, Bali}

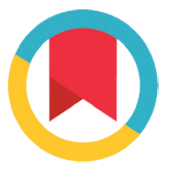

CrossMark

\author{
Ni Rai Sintarini, ${ }^{1 *}$ Komang Ayu Kartika Sari, ${ }^{2}$ I Gusti Agung Trisna Windiani, ${ }^{3}$ Anak Agung \\ Sagung Sawitri ${ }^{2}$
}

\begin{abstract}
Background and purpose: Pentavalent booster immunization coverage in Denpasar City is reported to be relatively low. This study aims to determine the prevalence and determinants of pentavalent immunization uptake.

Methods: A cross-sectional study was conducted in one banjar (hamlet) which was selected purposively in the work area of Public Health Centre (PHC) I West Denpasar, Bali Province. Banjar was selected with consideration of the diversity of local residents and migrants. All mothers who had children aged 3-5 years (138 people) in the banjar were chosen as respondents. Interviews were conducted in each respondent's house with variables included age, education, employment, parity, region of origin, knowledge on immunization, perception of susceptibility to and severity of disease, perceptions of benefits and barriers to immunization, sources of information, family support and acceptance of immunization. Data analysis was performed with poisson regression to determine the determinants of pentavalent booster immunization.
\end{abstract}

Results: The majority of respondents were aged $<30$ years, high school education or above, unemployed, had 1-2 children and were from Bali. The proportion of respondents who reported that their children had been given pentavalent immunization in children aged three to five years was found to be $78.3 \%$. Immunization prevalence was found to be higher in the population that originated from Bali (82.1\%). Determinants of pentavalent immunization are perceptions of benefits (APR=4.78; 95\%Cl: 1.35-16.96) and more sources of information (APR=1.21; 95\%Cl: 1.04-1.41).

Conclusion: The prevalence of pentavalent booster immunization is found to be lower than the average prevalence of the Bali Province but higher than the reported coverage of Denpasar City. The determinants of immunization acceptance was perception of high benefits and more sources of information. Information dissemination on the benefits of pentavalent booster immunization in children needs to be enhanced through health workers and various media to increase the coverage of pentavalent immunization.

Keywords: pentavalent immunization, perceived benefits, source of information, Bali

Cite This Article: Sintarini, N.R., Sari, K.A.K., Windiani, I.G.A.T., Sawitri, A.A.S. 2019. Prevalence and determinants of pentavalent booster immunization in children aged three to five years in Denpasar, Bali. Public Health and Preventive Medicine Archive 7(1): 20-25. D01:10.15562/phpma. v7i1.189

${ }^{1}$ Bali Wisnu Dharma Midwifery Academy,

${ }^{2}$ Department of Public Health and Preventive Medicine, Faculty of Medicine, Udayana University, ${ }^{3}$ Department of Pediatrics, Sanglah Hospital-Udayana University, Denpasar
*Correspondence to:

Ni Rai Sintarini, Bali Wisnu Dharma Midwifery Academy

raisintarini@yahoo.co.id

\section{INTRODUCTION}

Some diseases preventable by immunization are still found in particular areas in Indonesia. In 2014 there were 422 diphtheria cases in East Java with 9 deaths and 33 tetanus cases with 15 deaths. ${ }^{1}$ This was most likely related to the low coverage of basic immunization. The 2013 Indonesia Basic Health Research showed that complete basic immunization coverage was $59.2 \%$, incomplete $32.1 \%$ and not immunized $8.7 \%{ }^{2}$ Reasons for not immunizing included: fear of fever, family refusal, child becoming sick, distance to immunization facilities, lack of knowledge about immunization services and lack of time. ${ }^{2}$ Immunization coverage in Bali Province is higher than the national coverage and ranks second highest compared to other provinces with $80.8 \%$ complete, $18 \%$ incomplete and $1.2 \%$ not immunized. $^{2}$ The immunization coverage of Denpasar City was lower than the average of Bali Province which was $77.5 \%{ }^{3}$
The immunization program for the prevention of Haemophilus influenzae type b (Hib) infection began in 2013 and its administration is integrated with diphtheria, pertussis, tetanus and hepatitis $B$ immunizations. The packaging is combined into one dose called the pentavalent vaccine. Pentavalent immunization is given as basic immunization three times in children aged 2-11 months and one time booster at the age of 18-36 months. ${ }^{4}$

Data from the Bali Province Health Office shows that the coverage of the pentavalent booster immunization in 2015 amounted to $83.6 \%$ and Denpasar City was at the second lowest after Karangasem District with the coverage of $67.3 \% .{ }^{5}$ In Denpasar City, many private health services provide immunizations using their own vaccines from non-government suppliers and generally they do not report the number of immunized children to the local health office. In addition, the proportion of immigrants in 
the city of Denpasar is quite high, ${ }^{6}$ and this is likely related to the immunization coverage, as migrants mostly come from provinces with lower immunization coverage compared to Bali Province. ${ }^{2}$

PHC 1 West Denpasar is one of the PHCs in Denpasar City that has pentavalent booster immunization coverage of $47.3 \%,{ }^{7}$ which is below the Denpasar average. Informal interviews with 15 mothers of children under five who visited private practice doctors and PHC I West Denpasar show that nine children had received pentavalent booster immunization and five children had not received pentavalent booster for several reasons, namely late information regarding the age of pentavalent booster immunization, the assumption that basic immunization is enough, parents are busy working, feeling pity to see their child injected and the high price of vaccine. One child did not receive basic and booster immunizations for reasons of religious beliefs.

Studies related to the determinants of pentavalent immunization are very limited. Most studies report on the determinants of other basic and booster immunizations with varying results. Some studies show that the low coverage of basic and booster immunizations is associated with maternal age, ${ }^{8,9,10}$ education, ${ }^{8,11,12}$ employment, ${ }^{8,13}$ parity, ${ }^{9,14,15}$ knowledge, ${ }^{8,16,17}$ perception of immunization benefits, ${ }^{15,18,19}$ low family support ${ }^{8,13,20}$ and lack of information. ${ }^{15}$ Other studies show no association between immunization in infants and toddlers with maternal age, education and employment. ${ }^{15,21}$

This study aims to determine the association between maternal characteristics (age, education, employment, parity, region of origin), perceptions of susceptibility to and severity of disease, perceptions of the benefits and barriers to immunization, family support and number of information sources with acceptance of pentavalent booster immunization.

\section{METHODS}

The cross-sectional study was carried out in the working area of PHC 1 West Denpasar, Bali Province, where the pentavalent immunization coverage was lower than the target. PHC 1 West Denpasar covers 63 banjar (hamlets) and one of the 63 banjar was purposively chosen as a study location based on consideration of having a proportional number of indigenous and immigrant populations.

A minimum sample size of 134 children aged 3-5 years was calculated based on $95 \%$ confidence level, absolute precision of $17 \%$, proportion of complete immunization on good knowledge of $54 \%$ and on poor knowledge of $46 \% .{ }^{16} \mathrm{~A}$ household census was conducted in the selected banjar in February 2017 to collect the name of the heads of the families, number and age of children in the banjar. Of the 834 households, there were 138 households with children aged 3-5 years and all were selected as samples in this study. Interviews were conducted with mothers of children aged 3-5 years in each respondent's house in March-April 2017.

Data collected in this study refers to the Theory of PRECEDE-PROCEED ${ }^{22}$ and Health Belief Model $(\mathrm{HBM})^{23}$ which includes: acceptance of pentavalent booster immunization, age, education, employment, parity, knowledge, number of sources of information, family support, perceptions of susceptibility to and seriousness of disease, perceptions of benefits and barriers to pentavalent booster immunization. Mother's age is grouped into " $<30$ years" and " $\geq 30$ years" and education into "junior high school or lower" and "senior high school or higher". Knowledge includes about vaccine content, age of administration, benefits, contraindications, side effects and service providers. Furthermore, it is classified into "good" knowledge if the proportion of correct answer is $\geq 50 \%$ and "poor" if the proportion is $<50 \%$. Perception of susceptibility to disease was measured by one question about potential risk to get a disease if the child does not receive pentavalent booster immunization. Perception of the disease seriousness was measured by the presence or absence of fear of physical disability and life threatening impacts if they do not get pentavalent booster immunization and grouped into "high" seriousness if the score $=2$ and "low" if the score $\leq 1$. Perception of immunization benefits is measured by four questions about the benefits to prevent diseases, increase immunity, reduce disability and reduce mortality in children, which then grouped into "high" benefits if the score is $\geq 3$ and "low" if the score is $\leq 2$. Perception of barriers to immunization was measured by five questions regarding parents' lack of time to immunize children, expensive vaccine prices, fear of children will become ill, vaccines perceived to contain dangerous substances and family restrictions. Furthermore, it is grouped into perceived "high" barriers if the score is $\geq 3$ and "low" barriers if the score is $\leq 2$. Family support was measured by four questions about providing information, giving advice, giving funds and assisting to take child to the immunization provider, which was then grouped into "high" family support if the score $\geq 3$ and "low" family support if the score $\leq 2$. The number of information sources calculated from sources of information about pentavalent booster immunization that includes: mass media, TV/radio, brochures, families, health workers or others. Furthermore, it is grouped into "high 
number" of information sources if $\geq 4$ and "low number" of information sources if $\leq 3$.

Bivariate analysis was conducted with chi-square test, and multivariate analysis with Poisson regression using backward method to determine the association between independent variables with the acceptance of pentavalent booster immunization. This study has been approved by the Ethics Committee of the Faculty of Medicine, Udayana University/Sanglah General Hospital, Denpasar on February 21, 2017.

\section{RESULTS}

Table 1 shows the characteristics of respondents who were predominately less than 30 years old $(60.14 \%)$, had a high school education or higher (64.49\%), unemployed (60.87\%), had one or two children $(83.33 \%)$ and originally from Bali $(60.87 \%)$.

Table 2 shows the association between acceptance of pentavalent booster immunization and maternal sociodemographic characteristics, knowledge, perception, family support and information sources. Variables that have a $\mathrm{p}$ value $<0.25$ are included in the multivariate analysis model. These variables consisted of age, employment, region of origin, knowledge, perception of susceptibility to and seriousness of the disease, perceptions of benefits and barriers to immunization, number of sources of information and family support.

Table 3 shows the adjusted proportion ratios of variables which significantly associated with the acceptance of pentavalent booster immunization. The variables are the perception of high benefits $(\mathrm{APR}=4.78 ; 95 \% \mathrm{CI}: 1.35-6.96 ; \mathrm{p}=0.02)$ and the number of sources of information $\geq 4 \quad(A P R=1.21$; 95\%CI: 1.04-1.41; $\mathrm{p}=0.01)$.

\section{DISCUSSION}

Our study shows that $78.26 \%$ of children aged 3-5 years have received pentavalent booster immunization. This result is much higher than the pentavalent immunization coverage in PHC 1 West Denpasar in 2015 (47.3\%). ${ }^{24}$ Data on the coverage of pentavalent booster immunization in PHC were obtained from reports of private midwives, satellite PHC clinics and immunization registers, but does not include data from private health services that procure vaccines independently from non-government suppliers. The proportion of pentavalent booster immunization in this study was also relatively higher than the coverage in Denpasar City (67.3\%). ${ }^{24}$ The Denpasar City's coverage was obtained from public health services reports (PHCs and hospitals) without including private services. However, the coverage found in this study was lower when compared to the pentavalent booster immunization coverage in Bali Province (83.6\%). Of all districts/cities in Bali, coverages below the Bali Province's average were found in Denpasar City (67.3\%) and Karangasem District (58.9\%). ${ }^{5}$ This is likely related to the social geographic conditions in the two districts. Low coverage in Karangasem District is likely related to the geographical

\section{Table 1 Characteristics of respondents}

\begin{tabular}{lcc}
\hline Characteristics & $\mathbf{n}$ & $\%$ \\
\hline Age (years) & & \\
$\quad<30$ & 83 & 60.14 \\
$>30$ & 55 & 39.86 \\
Education & & \\
$\quad$ Senior high school or higher & 89 & 64.49 \\
$\quad$ Junior high school or lower & 49 & 35.51 \\
Employment & & \\
$\quad$ Unemployed & 84 & 60.87 \\
Employed & 54 & 39.13 \\
Parity & & \\
$1-2$ & 115 & 83.33 \\
$\geq 3$ & 23 & 16.67 \\
Region of origin & & \\
Outside Bali & 54 & 39.13 \\
Bali & 84 & 60.87 \\
Total & 138 & 100.00 \\
\hline
\end{tabular}


Table 2 Association between sociodemographic characteristics, knowledge, perceptions, family support and sources of information with acceptance of pentavalent booster immunization

\begin{tabular}{|c|c|c|c|c|c|}
\hline \multirow[b]{2}{*}{ Variables } & \multicolumn{2}{|c|}{ Immunized } & \multicolumn{2}{|c|}{ Not immunized } & \multirow[b]{2}{*}{$\mathbf{p}$} \\
\hline & $\mathbf{n}$ & $\%$ & $\mathbf{n}$ & $\%$ & \\
\hline \multicolumn{6}{|l|}{ Age (years) } \\
\hline$<30$ & 68 & 81.93 & 15 & 18.07 & 0.20 \\
\hline$\geq 30$ & 40 & 72.73 & 15 & 27.27 & \\
\hline \multicolumn{6}{|l|}{ Education } \\
\hline Senior high school or higher & 71 & 79,76 & 18 & 20.24 & 0.56 \\
\hline Junior high school or lower & 37 & 75.51 & 12 & 24.19 & \\
\hline \multicolumn{6}{|l|}{ Employment } \\
\hline Unemployed & 69 & 82.14 & 15 & 17.86 & 0.17 \\
\hline Employed & 39 & 72.22 & 15 & 27.78 & \\
\hline \multicolumn{6}{|l|}{ Parity } \\
\hline $1-2$ & 90 & 78.26 & 25 & 21.74 & 1.00 \\
\hline$\geq 3$ & 18 & 78.26 & 5 & 21.74 & \\
\hline \multicolumn{6}{|l|}{ Region of origin } \\
\hline Bali & 69 & 82.14 & 15 & 17.88 & 0.17 \\
\hline Outside Bali & 39 & 72.22 & 15 & 27.78 & \\
\hline \multicolumn{6}{|l|}{ Perception of susceptibility } \\
\hline Yes & 102 & 82.26 & 22 & 17.74 & $<0.01$ \\
\hline No & 6 & 42.86 & 8 & 57.14 & \\
\hline \multicolumn{6}{|l|}{ Perception of seriousness } \\
\hline High ( score $\geq 2$ ) & 104 & 85.25 & 18 & 14.75 & $\left.<0.01^{*}\right)$ \\
\hline Low $($ score $\leq 1)$ & 4 & 25.00 & 12 & 75.00 & \\
\hline \multicolumn{6}{|l|}{ Perception of benefits } \\
\hline High (score $\geq 3$ ) & 106 & 84.13 & 22 & 17.74 & $\left.<0.01^{*}\right)$ \\
\hline Low $($ score $\leq 2)$ & 2 & 16.67 & 8 & 57.14 & \\
\hline \multicolumn{6}{|l|}{ Perception of barriers } \\
\hline Low $($ score $\leq 3)$ & 106 & 84.13 & 20 & 15.87 & $\left.<0.01^{*}\right)$ \\
\hline High $($ score $\geq 4)$ & 2 & 16.67 & 10 & 83.33 & \\
\hline \multicolumn{6}{|l|}{ Knowledge } \\
\hline High (score $\geq 4$ ) & 102 & 81.60 & 20 & 15.87 & $<0.01$ \\
\hline Low (score $\leq 3$ ) & 6 & 46.15 & 10 & 83.33 & \\
\hline \multicolumn{6}{|l|}{ Family support } \\
\hline High ( score $\geq 3$ ) & 101 & 84.87 & 18 & 15.13 & $<0.01$ \\
\hline Low (score $\leq 2$ ) & 7 & 36.84 & 12 & 63.16 & \\
\hline \multicolumn{6}{|l|}{ Number of information sources } \\
\hline $\operatorname{High}(\geq 4)$ & 50 & 90.91 & 5 & 9.09 & $<0.01$ \\
\hline Low $(\leq 3)$ & 58 & 69.88 & 25 & 30.12 & \\
\hline Total & 108 & 78.26 & 30 & 21.74 & \\
\hline
\end{tabular}

${ }^{*}$ Analysed with Fisher Exact test 
Table 3 Adjusted proportion ratios of perceived benefits and the number of information sources to the acceptance of pentavalent booster immunization

\begin{tabular}{llcc}
\hline Variables & APR & $\mathbf{9 5 \%} \mathbf{C l}$ & $\mathbf{p}$ \\
\hline $\begin{array}{l}\text { Perception of benefits } \\
\quad\end{array}$ & & & \\
$\quad$ Low (score $\leq 2)$ & 1.00 & $1.35-6.96$ & 0.02 \\
$\quad$ High (score $\geq 3$ ) & 4.78 & & \\
Number of information sources & & & 0.01 \\
$\quad$ Low $(\leq 3)$ & 1.00 & $1.04-1.41$ & \\
High $(\geq 4)$ & 1.21 & & \\
\hline
\end{tabular}

conditions of the district, while lower coverage in Denpasar City might be related to the large number of migrant residents. In our study, the coverage of pentavalent immunization in those originally from Bali was higher than that of the migrant population, which were $82.14 \%$ and $72.22 \%$, respectively.

The results of our study show only two factors that are significantly associated with the acceptance of pentavalent booster immunization, namely the perception of benefits and the number of information sources. Other components in the HBM, which consisted of the perception of susceptibility, seriousness and barriers, however were not found to be significantly associated with the acceptance of pentavalent booster immunization. The perceived benefits of pentavalent booster immunization in this study included the roles of vaccines in preventing disease (92.03\%), increasing immunity (91.30\%), reducing disability $(91.30 \%)$ and reducing morbidity from disease (91.30\%). Studies on the acceptance of pentavalent immunization is very limited so that the results of this study are compared mostly with the results of basic immunization studies. The results of this study are consistent with studies in Aceh $^{18}$ and Surakarta ${ }^{19}$ which show a significant association between perceived high benefits and the completeness of basic immunizations. Our study is also in line with a study in a developed country (Atlanta, USA) which shows that parents who had lack of understanding about the benefits of basic immunization tend to not provide complete immunization. $^{25}$

This study shows that mothers who received information from many sources tend to accept pentavalent booster immunization. In this study, most of the respondents received information from health workers $(89.87 \%)$. Other sources of information consisted of brochures/posters (42.46\%), family members (33.33\%), newspapers (19.57\%), television/radio (14.49\%) and the internet $(12.32 \%)$. Other studies which show the association between immunization acceptance and the number of information sources remain very limited. Other studies only show the association between immunization acceptance and history of receiving information.
A study in East Jakarta shows that there is no association between information obtained from health workers, educational institutions, print media and the internet with the completeness of basic immunization for children. ${ }^{15}$ The different results is likely due to the different sample characteristics in both study locations. In addition, the Jakarta study was conducted in 2009, when media information was lacking as opposed to when our study was conducted in 2017.

Our study limitation is the fact that it was carried out only in one banjar (hamlet) that selected purposively. Therefore that the interpretation and application of the results into a wider population should be conducted with caution.

\section{CONCLUSION}

The prevalence of pentavalent booster immunization in the work area of PHC 1 West Denpasar was $78.26 \%$. The determinants of immunization acceptance were perception of high benefits and higher number of information sources. Information about the benefits of pentavalent booster immunization in children needs to be disseminated through health workers and various other media in order to increase the uptake of pentavalent booster immunization.

\section{ACKNOWLEDGMENT}

We would like to thank the Head of PHC 1 West Denpasar, Head of the banjar of Padang Sambian Village, West Denpasar and all respondents who participated in this study.

\section{REFERENCES}

1. East Java Province Health Office. Profil Kesehatan Provinsi Jawa Timur [Health Profile of East Java Province]. East Java: East Java Province Health Office; 2014.

2. Ministry of Health of Indonesia. Riset Kesehatan Dasar (Riskesdas) Tahun 2013 [The 2013 Indonesia Basic Health Research]. Jakarta: Kementerian Kesehatan RI; 2013.

3. Ministry of Health of Indonesia. Riset Kesehatan Dasar dalam Angka-Riskesdas Provinsi Bali Tahun 2013 [Basic Health Research in Number-The 2013 Bali Province Basic Health Research]. Jakarta: The Ministry of Health of Indonesia; 2013. 
4. The Ministry of Health of Indonesia. Petunjuk teknis introduksi imunisasi DPT-HB-Hib (pentavalen) pada bayi dan pelaksanaannya pada anak batita [The technical guidelines on the introduction of DPT-HB-Hib (pentavalent) immunization for babies and its implementation among children aged under five year old]. Jakarta:, 2013.

5. Bali Province Health Office. Laporan cakupan imunisasi pentavalen lanjutan [Report on the coverage of pentavalent booster immunization]. Denpasar: Bali Province Health Office; 2015.

6. Bali Province Statistics Office. Penduduk Provinsi Bali menurut kabupaten/kota, jenis kelamin, dan status migrasi seumur hidup hasil Sensus Penduduk Tahun 2010 [Population of Bali Province based on district/ city, sex dan lifetime migration status as shown in the Population Census Year 2010]. Denpasar; 2018. [cited 2018 February 15]. Available at: https://bali.bps. go.id/statictable/2018/02/15/37/penduduk-provinsi-bali-menurut-kabupaten-kota-jenis-kelamin-dan-status-migrasi-seumur-hidup-hasil-sensus-penduduk-2010. html

7. Puskesmas I Denpasar Barat. Data Puskesmas I Denpasar Barat Tahun 2015 [The 2015 Data of West Denpasar I Public Health Centre]. Denpasar; 2015.

8. Anisah M, Syamsulhuda B, Bagoes W. Beberapa faktor yang berhubungan dengan praktik imunisasi pentavalen booster di wilayah kerja Puskesmas Mangunsari Salatiga [Factors associated with pentavalent booster immunization in the working area of Mangunsari Public Health Center Salatiga]. Jurnal Kesehatan Masyarakat (e-Journal). 2016; 3(4):949-959.

9. Fatiregun AA, Anselm O. Maternal determinants of complete child immunization among children aged 12-23 months in a southern district of Nigeria. Elsevier. 2012; 30: 730-736.

10. Ganczak M, Dmytrzyk-daniłów G, Karakiewicz B. Determinants influencing self-paid vaccination coverage in $0-5$ years old Polish children. Elsevier. 2013; 31: 5687-5692.

11. Kusuma YS1, Kumari R, Pandav CS, Gupta SK. Migration and immunization: determinants of childhood immunization uptake among socioeconomically disadvantaged migrants in Delhi, India. Tropical Medicine and International Health. 2010; 15(11): 1326-1332.

12. Rati AP, Parjo, Hidayah N. Analisis faktor-faktor yang mempengaruhi kelengkapan imunisasi dasar pada batita usia 9-24 bulan di Desa Pal IX Kecamatan Sungkep Kakap Kabupaten Kubu Raya (skipsi) [Analysis of factors which influence the completeness of basic immunizaton in children aged 9-24 months in Pal IX Village, Sungkep Kakap Sub-District, Kubu Raya District]. Pontianak: Tanjung Pura University; 2015.

13. Nath B1, Singh JV, Awasthi S, Bhushan V, Kumar V, Singh SK. A study on determinants of immunization coverage among 12-23 months old children in urban slums of Lucknow District, India. Indian Journal Medical Sciences 2007; 61(11): 598-606

14. Negussie A, Kassahun W, Assegid S, Hagan AK. Factors associated with incomplete childhood immunization in Arbegona District, Southern Ethiopia: a case-control study. BioMed Central Public Health 2016; 16:27.
15. Prayogo A, Adelia A, Cathrine, Dewina A, Pratiwi B, Ngatio B, et al. Kelengkapan imunisasi dasar pada anak usia 1-5 tahun [Basic immunization completeness among children aged 1-5 years old]. Sari Pediatri. 2009; 11(1): 15-20.

16. Animaw W, Taye W, Merdekios B, Tilahun M, Ayele G. Expanded program of immunization coverage and associated factors among children age 12-23 months in Arba Minch Town and Zuria. BioMed Central. 2014; 14: 464.

17. Albertina M, Febriana S, Firmanda W, Permata Y, Gunardi H. Kelengkapan imunisasi dasar anak balita dan faktor-faktor yang berhubungan di Poliklinik Anak beberapa Rumah Sakit di Jakarta dan sekitarnya pada Bulan Maret 2008 [Basic immunization completeness among children under five year old and its factors at the pediatric polyclinic in several hospitals in Jakarta in March 2008]. Sari Pediatri. 2009; 11(1): 1-7.

18. Suryawati I, Bakhtiar, Abdullah A. Cakupan Imunisasi Dasar Anak Ditinjau dari Pendekatan Health Belief Model [The coverage of children basic immunization from the perspective of Health Belief Model]. Jurnal Ilmu Keperawatan. 2016; 4: 1.

19. Puri YE, Murti B, Demartoto A. Pengaruh persepsi ibu tentang imunisasi ditinjau dengan Health Belief Model terhadap kelengkapan status imunisasi (thesis) [The influence of mother's perception of immunization from the perspective of Health Belief Model on immunization completeness (thesis)]. Solo: Universitas 11 Maret; 2016.

20. Fajriah I. Hubungan pengetahuan ibu dan dukungan keluarga dengan status imunisasi TD pada sub PIN difteri [The association between mother's knowledge and family support with TD immunization status in national diphteria immunization week]. Jurnal Berkala Epidemiologi 2014; 2(3) 404-415.

21. Afriani T, Andrajati R, Supardi S. Faktor-faktor yang berhubungan dengan kelengkapan imunisasi dasar pada anak dan pengelolaan vaksin di puskesmas dan posyandu Kecamatan X, Kota Depok [Factors associated with basic immunization completeness among children and vaccine management in public health center and integrated health services in X Sud-District, Depok City]. Buletin Penelitian Sistem Kesehatan. 2014; 17(2): 135-142.

22. Green L, Kreuter M. Health Program Planning \& Evaluation. 4th ed. New York, 2005.

23. Rosenstock IM, Strecher VJ, Becker MH. Social Learning Theory and the Health Belief Model. 1974.

24. Dinas Kesehatan Kota Denpasar. Laporan cakupan imunisasi pentavalen lanjutan [Report on the coverage of pentavalent booster immunization]. Denpasar, 2015.

25. Smith PJ, Humiston SG. Parental delay or refusal of vaccine doses, childhood vaccination coverage at 24 months of age, and the Health Belief Model. Public Health Report. 2011; 126: 135-146.

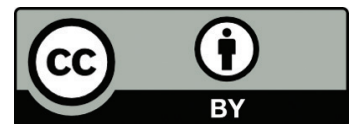

This work is licensed under a Creative Commons Attribution 